\title{
Persistent metopic suture can mimic the skull fractures in the emergency setting?
}

\author{
G. Bademci; T. Kendi and F. Agalar
}

Departments of Neurosurgery, Radiology and Surgery. Faculty of Medicine. University of Kırıkkale. Turkey.

\section{Summary}

Metopism is partially or totally persisting suture extending from the nasion to the anterior angle of the bregma. The time of physiological closure of the metopic suture varies from birth to 8 years of age. Widely accepted closuring time is approximated at 2 years of age. Although formerly reported skull studies mentioned the persistent metopic suture, it is extremely rare in clinical practice. We presented a trauma case of 43 years of age who was demonstrated radiologically to have a persisting suture. Persistent metopic suture may be misdiagnosed as a vertical traumatic skull fracture extending in the mid-line in head trauma patients. Therefore the surgeon should be aware of this anatomical condition in the primary and secondary surveillance of the traumatized patient and during surgical intervention including especially frontal craniotomy. Reconstructed tomography scan demonstrating sutural closuring status may provide additional informative value in the diagnostic sequence superior to plain $\mathrm{X}$-ray in the emergency setting.

KEY WORDS: Metopic suture. Metopism. Vertical fracture. Trauma

La sutura metópica persistente ¿puede simular fractura de cráneo en un escenario de urgencias?

\section{Resumen}

El cuadro denominado metopismo consiste en la persistencia parcial o total de la sutura que se extiende desde el nasion hasta el ángulo anterior del bregma. El tiempo de cierre de la sutura metópica oscila desde el momento del nacimiento hasta los ocho años. El criterio más aceptado es que el cierre suele terminar a los dos años. Algunos estudios mencionaban la posibilidad

Recibido: 30-05-06. Aceptado: 10-07-06 de la persistencia de dicha sutura a lo largo de toda la vida, pero es excepcional en la práctica clínica. Se presenta un caso de traumatismo de 43 años de edad, que mostraba en la radiología la falta de cierre de dicha sutura metópica. Aunque puede considerarse como una anomalía rara, también puede con una fractura vertical frontal, cercana a la línea media, en pacientes con traumatismos. Por lo tanto, el cirujano debe percatarse de este hecho anatómico en la atención inicial del paciente y en la planificación de una craneotomía bifrontal. En este trabajo se señala que la reconstrucción tridimensional de la TAC añade una información valiosa al estudio radiológico convencional en la unidad de urgencias.

PALABAS CLAVE: Sutura metópica. Metopismo. Fractura vertical. Trauma

Introduction

The cranial sutures and their evolution form one of the question most interesting in the field of cranial growing and shaping. Metopic suture is a kind of dentate suture extending from the nasion to the bregma. Its timing of closure is still controversial. Previously reported closuring time of the metopic suture is accepted one to three years of age and is allowed up to 8 years ${ }^{8}$. Caffey ${ }^{2}$ claimed that it might be persisted up to the sixth year and even throughout life in about $10 \%$ of cases in skull studies. The incidence of the metopism and difference in shapes varies by races ${ }^{1}$. Vertical frontal bone fractures may be easily misdiagnosed with persisted metopic variations. The reconstructed 3-D format CT scan may provide informative value in comparison to conventional X-rays in the diagnostic sequence of traumatized patients.

\section{Case Presentation}

A-43-year old man was admitted to the neurosurgery department of the University of Kirikkale, Faculty of Medicine complaining headache and head trauma history. 


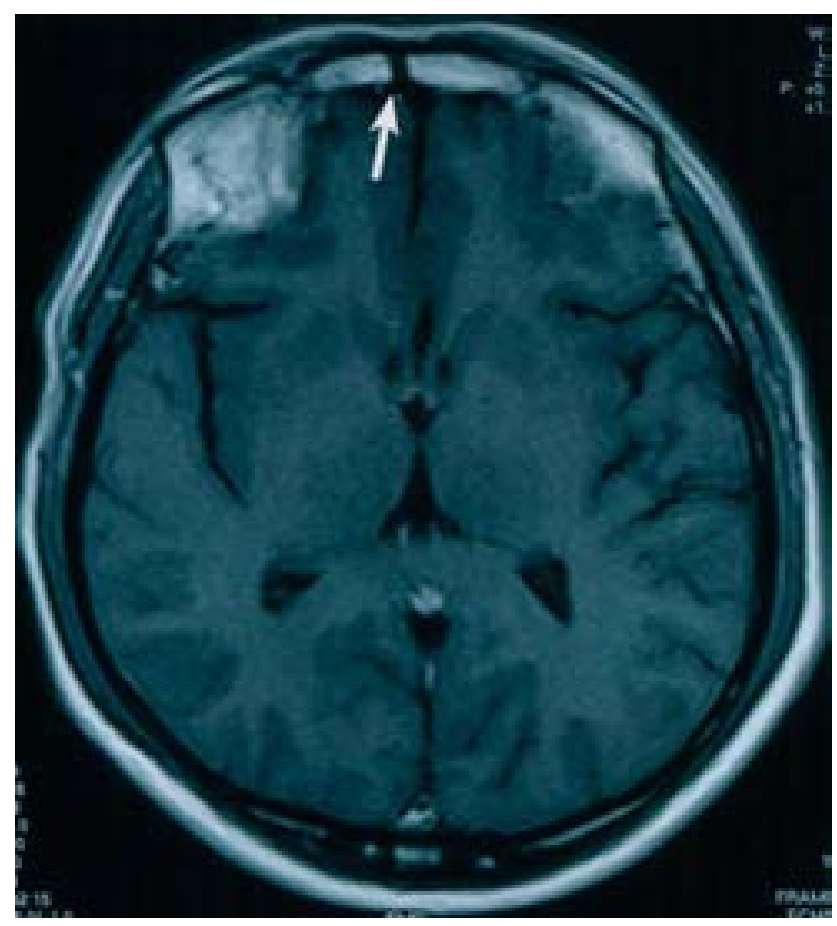

Figure 1. Transverse MR image shows open metopic suture (arrow).

Neurological examination was completely normal. Plain $\mathrm{X}$-ray graphy showed mid-frontal vertical diastesis. Computed tomography (CT) and Magnetic Resonance Imaging (MRI) were planned to differantiate another abnormality related with previous head trauma. CT and MRI revealed no abnormality except $2 \mathrm{~mm}$ diastesis of metopic suture (Figure 1). Then, 3D CT and Multiplanar Reformat (MPR) scans performed and clearly demonstrated open metopic suture (Figure 2).

\section{Discussion}

Anatomo-physiological patterns of the sutural areas of the skull and the growing and closuring process of the sutures which constitute the craniofacial shaping were widely studied. Attention has been paid to the sutural fusion earlier than expected because of their functional importance for the brain development. Delayed or persisted closuring of the sutures form particular interest of the descriptive and experimental studies rather than clinical point of view attributable to its rarity.

Metopic suture is a kind of dentate suture ${ }^{1}$. Normal or physiologic closuring time of the metopic suture is controversial in the current literature. Stricker ${ }^{10}$ stated that metopic suture is normally closed at birth, while some authors proposed that the metopic suture doesn't fuse until the second years of age; the others accepted this age as the beginning time of the closure ${ }^{3,7}$. Mathijissen et al. claimed

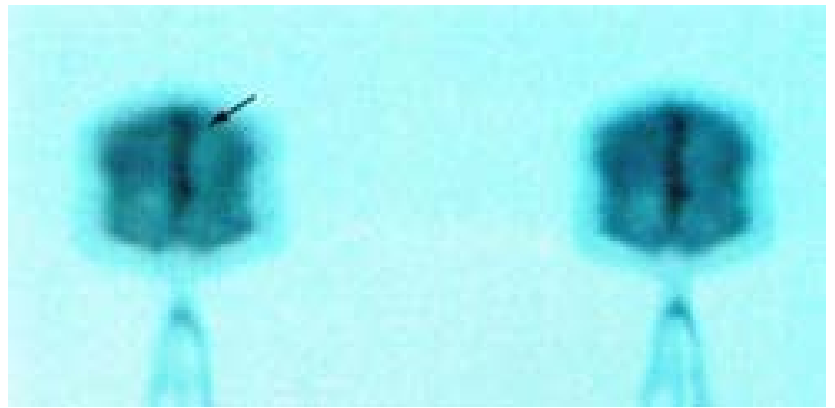

Figure 2. Multiplanar reformat CT image demonstrates partial linear type metopic suture (arrow)

that ossification is completed at up to eight years of life ${ }^{8}$. $\mathrm{Vu}$ et $\mathrm{al}^{11}$ indicated that metopic fusion may normally occur as early as three months of age, and that complete fusion occured by nine months of age in all patients in their series with using reconstructed 3D CT scans.

In some cases, metopic suture persists as an incomplete or complete suture extending from the nasion to the anterior angle of the bregma and the condition is called metopism or sutura frontalis persistens. Incomplete types of metopic suture shows variations in the superior, middle and lower part of the frontal bone and are of different shapes. The most common shape observed is the linear type ${ }^{1}$. In the presented case, a partial linear type persistent metopic suture was observed.

The etiology of metopic persistence is as unclear as why it demonstrates synostosis. Manzaranes et $\mathrm{al}^{5}$ showed that the chondroid tissue is responsible for sutural closure and of the maintenance of an open sutural space by a process of active resorption. Levine ${ }^{5}$ demonstrated the critical role of the dura mater-suture complex in determining metopic suture patency in animal models. Longaker and $\mathrm{Most}^{6,9}$ indicated that some cytokines showed increased expression during active cranial suture fusion. The open states of the sutural fissure are maintained by means of osteoclastic resorption ${ }^{7}$.

The hypothesis that sutural variants are not under direct genetic control but are secondary characteristics, brought about by "ontogenetic stress", including artificial cranial deformation. The factors controlling the occurrence of some sutural variants which show a tendency for a predominant occurrence in males may at least in part differ from those of other hypostotic trauts. On a world scale, the trauts presented in Hanihara et al study showed distinctive patterns of geographic variation ${ }^{4}$.

In a patient with head injury, delayed closure of the metopic suture may be erroneously treated like a vertical fracture. Differential diagnosis should be meticulously planned. Persistent metopic suture can easily be diagnosed by antero-posterior X-rays. Although plain X-ray is enough to diagnose this anatomical variation, it may be strongly 
misdiagnosed with vertical fractures in the emergency setting. 2D scans of the head may be reconstructed to 3D format for the evaluation of the metopic suture patency status. Multiplanar Reformat of CT scans also give valuable information about shape ${ }^{6}$, extent and closuring status ${ }^{11}$ of metopic suture. Especially when the cranial tomography is indicated in head injury with low Glasgow Coma Score, 3D format may be helpful in the diagnosis of metopism. On the other hand, the surgeon should be aware of this anatomical condition, while performing frontal craniotomy for any reason.

As a conclusion, despite the fact that metopism is not a rare anomaly as has been previously described in skull studies, diagnosing the persistent suture clinically in suspected head trauma patient may be problematic as it may be considered an evidence of traumatic vertical fractures. Multiplanar reformat and if possible 3D CT scans are helpful to demonstrate the type and extent of the suture and to verify the pathology.

\section{References}

1. Ajmani, M.L., Mittal, R.K., Jain, S.P.: Incidence of the metopic suture in adult Nigerian skulls. J Anat 1983; 137: 1: 177-183.

2. Caffey, J.: Pediatric X-ray diagnosis, 1978 , $7^{\text {th }}$ ed. Vol 1, London Year Book, Medical Publication Inc., pp 10-25.

3. Cohen, N.M. Jr.: Sutural biology and the correlates of craniosynostosis (review) Am J Med.Genet 1993; 47: 581-561.

4. Hanihara, T., Ishida, H.: Frequency variations of discrete cranial traits in major human populations. II. Hypostotic variations. J Anat 2001; 198: 707-725.

5. Levine, J., Bradley, J., Roth, D., McCarthy, J., Longaker, M.: Studies in cranial suture biology: Regional dura mater determines overlying suture biology. Plast Reconstr Surg 1998; 101: 1441-1447.

6. Longaker, M.T.: Role of TGF-beta signaling in the regulation of programmed cranial suture fusion. J Craniofac Surg 2001; 12: 389-390.

7. Manzaranes, M.C., Goret-Nicaise, M., Dhem, A.: Metopic sutural closure in the human skull. J Anat 1998; 161: 203215.

8. Mathijissen, I.M., Vaadrager, J.M., can der Meulen, J.C., Pieterman, H., Zonneveld, F.W., Dreiborg, S., Vermeij-Keers, C.: The role of bone centers in the pathogenesis of craniosynostosis: an embryologic approach using CT measurements in an isolated craniosynostosis and Apert and Crouzon syndromes. Plast Reconstr Surg 1996; 98: 17-26.

9. Most, D., Levine, J., Chang, J., Sung, J., McCarthy, J., Schendel, S., Longaker, M.: Studies in cranial suture biology: Up-regulation of transforming growth factor B1 and basic fibroblastic growth factor mRNA correlates with posterior frontal cranial suture fusion in the rat. Plast Reconstr. Surg 1998; 101: 1431-1440.

10. Stricker, M.: Craniofacial anatomy (surgical and functional) Edinburgh: Churchill-Livingstone. 1990.

11. Vu, H.L., Panchal, J., Parker, E., Levine, N., Francel, P.: The timing of physiologic closure of the metopic suture: A review of 159 patients using reconstructed 3D CT scans of the craniofacial region. The journal of Craniofacial Surgery 2001; 12: $527-532$.

Bademci, G.; Kendi; T.; Agalar, F.: Persistent metopic suture can mimis de skull fractures in the emergency setting? Neurocirugía 2007; 18: 238-240.

Corresponding address: Gulsah Bademci. Buketkent mah. Iller sitesi 9.Blok No: 9. 06530 Cayyolu/Ankara. Turkey. 